\title{
Cultura médica e decisões reprodutivas entre mulheres infectadas pelo vírus da Aids
}

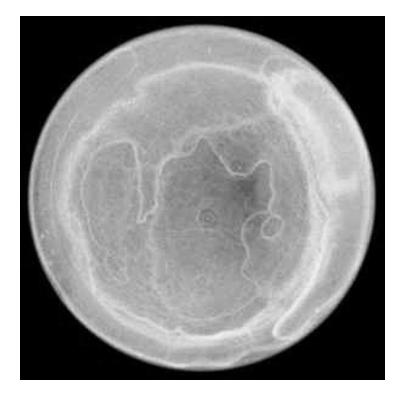

Daniela Riva Knauth 1 Regina Maria Barbosa ${ }^{2}$ Kristine Hopkins ${ }^{3}$ Marion Pegorario ${ }^{4}$ Regina Fachini ${ }^{5}$

KNAUTH, D. R. ET AL. Medical culture and reproductive decisions among women infected with Aids, Interface Comunic, Saúde, Educ, v.6, n.11, p.39-54, 2002.

HIV+ pregnant women face a range of medical information, prescriptions and practices that transform this period into a unique situation relative to previous pregnancies and experiences. This article tries to show which are the factors that affect HIV+ pregnant women's reproductive choices, especially as regards type of delivery and the decision on feminine sterilization adopted, as well as their implications. We present data from a study of 60 women, interviewed in the cities of São Paulo and Porto Alegre. Testing positively for AIDS changes a woman's perception of childbirth, so that it becomes a medical prescription; her preferences take second place. Furthermore, the type of health service in which these women receive prenatal care appears to be a crucial factor, both as regards the type of delivery the woman desires and concerning whether she realizes her preference or not. The fact that these women feel that their childbirth preferences are determined by medical prescription, being therefore largely independent of their "real" desires or previous experiences, cause many women to view the HIV+ positive birth experience as more difficult than previous deliveries or worse than was expected.

KEY-WORDS: Contraceptive behavior; reproductive medicine; Acquired immunodeficiency syndrome; delivery.

As gestantes infectadas pelo vírus da Aids defrontam-se com um conjunto de informações, prescrições e práticas que tornam este período particular em relação a outras gestações e experiências. O presente artigo busca evidenciar os fatores que condicionam as escolhas reprodutivas das gestantes HIV+, em especial no que se refere ao tipo de parto e decisão por esterilização feminina adotado, bem como suas implicações. Os dados apresentados resultam de uma pesquisa desenvolvida nas cidades de São Paulo e Porto Alegre, onde foram entrevistadas sessenta mulheres. A condição de soropositividade para o HIV faz com que o parto seja percebido, pelas gestantes, como uma prescrição médica, deixando o desejo em segundo plano. Mas, além deste fator, o tipo de serviço ao qual a gestante encontra-se vinculada aparece como determinante, tanto para a indicação fornecida como para sua concretização ou não. $\mathrm{O}$ fato das expectativas relacionadas ao parto serem determinadas por uma prescrição médica, pouco dependente da vontade ou experiências anteriores, faz com que para muitas mulheres esta experiência seja percebida como mais difícil que os partos anteriores ou pior que o esperado.

PALAVRAS-CHAVE: Comportamento contraceptivo; saúde reprodutiva; Síndrome de Imunodeficiência Adquirida; parto.

\footnotetext{
${ }_{1}^{1}$ Professora do Departamento de Medicina Social, Universidade Federal do Rio Grande do Sul, UFRGS; Pesquisadora do Núcleo de Pesquisa em Antropologia do Corpo e da Saúde (NUPACS/UFRGS). <knauth@portoweb.com.br>

2 Pesquisadora do Núcleo de Estudos Populacionais (NEPO), Universidade Estadual de Campinas, UNICAMP; Pesquisadora do Centro de Referência para Aids, Secretaria Estadual de Saúde, São Paulo.<rbarbosa@nepo.unicamp.br>

${ }_{3}^{3}$ Pesquisadora Associada, Population Research Center, Universidade do Texas, Austin.. <khopkins@prc.utexas.edu>

${ }^{4}$ Assistente de pesquisa do Núcleo de Pesquisa em Antropologia do Corpo e da Saúde (NUPACS); Técnica em pesquisa do IBGE. <mcpeg@terra.com.br>

${ }^{5}$ Assistente de pesquisa do Núcleo de Estudos Populacionais (NEPO/UNICAMP).<rfacchini@uol.com.br>
} 
Os dados sobre a epidemia de Aids no Brasil indicam claramente o crescimento do número de mulheres infectadas. Estas mulheres, por serem jovens e encontrarem-se em pleno período reprodutivo, colocam em cena o problema da transmissão do vírus ao bebê. Diversas medidas já foram acionadas a fim de reduzir a taxa de transmissão vertical (mãe-bebê), tais como o oferecimento regular do teste anti-HIV durante a gestação, o uso de medicação específica para as gestante e recém-nascidos e a disponibilização de exames de contagem de carga viral e CD4. Outra medida que tem sido preconizada pela literatura internacional para a redução da taxa de transmissão vertical é a cesariana eletiva ${ }^{6}$. Este procedimento, contudo, não tem sido aplicado da mesma forma por todos os serviços que atendem gestantes HIV+, pois questionam-se diversos aspectos como relação custo/ benefício e maior morbidade associada à cesariana. Dessa forma, alguns serviços preconizam uma avaliação que leva em consideração o índice de CD4 e carga viral da gestante e outros consideram exclusivamente as indicações clínicas para a realização de uma cesariana (posição/tamanho do feto, falta de dilatação, tempo de gestação etc.).

As gestantes infectadas pelo vírus da Aids confrontam-se, assim, nos serviços de saúde, com um conjunto de informações, prescrições e práticas com as quais necessitam, de alguma forma, relacionar-se. Elas precisam aprender a utilizar adequadamente a medicação (tanto a sua como a do bebê), realizar os exames solicitados, aceitar o tipo de parto indicado etc. Mas se muito se sabe sobre os aspectos clínicos da transmissão vertical do HIV, pouco sabemos ainda sobre como as gestantes vivenciam este período. O presente artigo pretende contribuir para esta discussão refletindo, a partir de dados de pesquisa, sobre os fatores que condicionam as escolhas reprodutivas das gestantes $\mathrm{HIV+}$, em especial no que se refere ao tipo de parto e método contraceptivo adotado, bem como a respeito de suas implicações.

\section{A pesquisa}

O material que fundamenta esta discussão é resultado de uma pesquisa desenvolvida com gestantes infectadas pelo vírus da Aids em duas cidades brasileiras, São Paulo e Porto Alegre. Foram entrevistadas no total sessenta mulheres, distribuídas em três tipos distintos de organização da atenção ao pré-natal e ao parto, todas elas vinculadas à rede pública de assistência: 1) serviço pré-natal de referência para Aids ligado à universidade, com referência garantida para o parto; 2) serviço de pré-natal referência para Aids próprio do SUS e referência garantida para o parto; 3) serviço de prénatal especializado para gestante soropositiva sem referência garantida para o parto. Tanto as duas cidades como os tipos de serviços foram escolhidos por terem, teoricamente, diferentes posições em relação ao tipo de parto $e$ contracepção.

A metodologia utilizada foi a qualitativa e os dados foram coletados por meio de entrevistas semi-estruturadas. A fim de poder melhor avaliar a correspondência ou não das expectativas femininas em relação à gravidez, tipo de parto e método contraceptivo adotado, cada mulher foi entrevistada
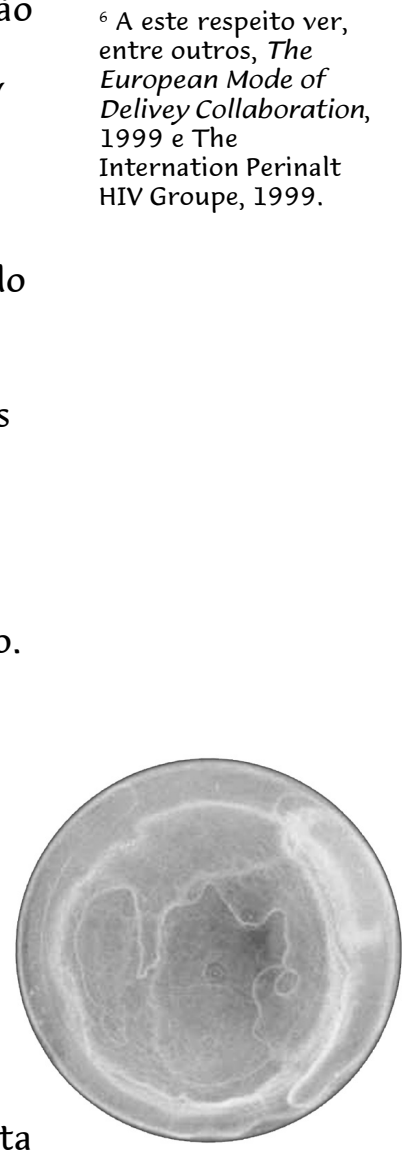
7 O projeto maior intitula-se Esterilização, cesariana e escolhas contraceptivas, ver Potter et al., 2001a e b. em dois momentos diferentes: durante a gestação e após o nascimento do bebê. Buscou-se, assim, analisar os fatores que concorrem para a concordância ou não das expectativas primeiras da gestante com a realidade por ela vivenciada.

Esta pesquisa faz parte de um projeto maior ${ }^{7}$ que busca compreender as razões do aumento surpreendente, verificado no Brasil, do número de partos cirúrgicos e de esterilização feminina. O objetivo deste projeto mais amplo é investigar a demanda das mulheres pelo parto cesáreo e pela esterilização e a influência da performance dos médicos nesta opção, sobretudo quando estas duas práticas encontram-se vinculadas. Foram excluídos deste projeto os serviços especializados em gestações de risco e, neste sentido, o sub-projeto que embasa o presente artigo pretende dar conta de um grupo específico de gestantes que foram propositadamente excluídas do projeto maior.

\section{Os diferentes níveis que interferem nas decisões reprodutivas}

Refletindo sobre os dados dos grandes estudos quantitativos desenvolvidos na Europa nos últimos anos sobre comportamento sexual da população, Bajos e Marquet (2000) sugerem a necessidade de romper com uma perspectiva de avaliação de risco centrada unicamente nas decisões individuais. Segundo estes autores, é fundamental desenvolver uma perspectiva relacional do risco, visto que as relações e os significados são construídos em diferentes contextos e níveis sociais. Neste sentido, eles propõem, a partir do trabalho de Van Clampenhoudt et al. (1997), contextualizar as decisões e práticas dos indivíduos em quatro níveis: 1) o contexto institucional e macro-social; 2) o contexto mais limitado do relacionamento social (the relationship's close social context); 3) o contexto da própria interação entre os parceiros; 4) o nível intrapessoal.

O primeiro nível seria o mais estrutural, no qual se enquadrariam os aspectos sócio-econômicos mais amplos, mas também aqueles de ordem valorativa como, por exemplo, o gênero. O segundo seria um nível intermediário, que poderíamos pensar como o contexto sócio-cultural local que determina um conjunto mais restrito de valores e significados. $\mathrm{O}$ terceiro nível seria aquele no qual se situam os relacionamentos interpessoais propriamente ditos, isto é, as relações sociais. Poderíamos pensar este nível, utilizando uma metáfora interacionista, como "a cena" que se desenvolve entre os diferentes personagens em questão, em que cada um tem um papel que procura desempenhar em conformidade com as expectativas dos demais. Por fim, o último nível seria aquele mais restrito às características propriamente individuais, tais como personalidade, história de vida, experiências etc.

Os próprios autores reconhecem que esta é uma divisão exclusivamente analítica, pois na prática todos os níveis encontram-se extremamente interligados. Eles estão o tempo todo vinculados, determinando uns aos outros.

Ao pensarmos a reprodução no contexto da Aids é fundamental contextualizarmos, primeiramente, o valor atribuído pela cultura à 
maternidade. No caso específico deste trabalho, por tomarmos mulheres, em sua grande maioria, pertencentes ao que poderíamos denominar de grupos populares, é necessário reconhecer, conforme vários estudos demonstram (Bilac, 1978; Duarte, 1986; Fonseca, 1985; Salem, 1981; Sarti, 1996) a importância conferida por este segmento social à família. Esta constitui um dos principais valores do sistema simbólico do grupo e, como tal, é um elemento fundamental de determinação da identidade social ${ }^{8}$. Neste sentido, as decisões a respeito da procriação - mesmo no caso especifico das mulheres portadoras do vírus da Aids - aparecem sempre permeadas pelo valor-família ${ }^{9}$.

Desse modo, analisando as decisões reprodutivas no contexto das gestantes $\mathrm{HIV}+$, em especial aquelas relacionadas ao tipo de parto $e$ contracepção, parece-nos bastante adequado pensar estes diferentes níveis na medida em que nesse contexto específico estão em questão aspectos que ultrapassam, em muito, o nível de decisão individual. Assim, se num primeiro momento devemos considerar a importância da cultura na valorização da maternidade, outros níveis parecem agir nas decisões a serem tomadas pelas mulheres durante e após a gestação. Estamos falando de mulheres que devem "optar" por um tipo específico de parto e método contraceptivo levando em consideração fatores que não dizem respeito apenas à vontade individual ou experiências passadas, mas devem contemplar as possibilidades maiores ou menores de transmissão do vírus ao feto, as especificidades dos serviços de pré-natal e de parto, o conhecimento médico do momento, entre outros fatores.

No caso das gestantes infectadas pelo vírus da Aids, é fundamental levarmos em consideração o contexto institucional no qual estas gestantes estão inseridas. Pois se no caso das gestantes em geral poderíamos supor que as decisões reprodutivas se dão, em especial, no nível do relacionamento entre os parceiros e no nível intrapessoal, no caso das gestantes HIV+o contexto institucional parece assumir um peso maior. Gostaríamos de sugerir, assim, que para essas mulheres as decisões reprodutivas são, antes de tudo, um problema médico e que embora elas possuam experiências $e$ desejos neste sentido, estes encontram-se submetidos, em última instância, à prescrição médica e à conduta adotada pelo serviço ao qual essas mulheres estão vinculadas.

A fim de explorar esta hipótese analisaremos os dados coletados entre as gestantes, buscando confrontar as expectativas iniciais, o tipo de parto realizado e a escolha contraceptiva das mulheres, com o tipo de serviço no qual fizeram o acompanhamento pré-natal, bem como a cidade na qual foram captadas.

\section{Entre o desejo e a prescrição}

Nas entrevistas realizadas durante o pré-natal aparece de forma bastante evidente que as expectativas das mulheres em relação ao tipo de parto estão marcadas, primeiramente, pela condição de soropositiva para o HIV e, em segundo lugar, pelo tipo de serviço pré-natal freqüentado. O primeiro elemento é o que explica o fato de que mais da metade das entrevistadas

\author{
${ }^{8}$ Conforme Duarte \\ (1986, p.175), "o \\ Valor-Família abarca \\ um certo número de \\ qualidades \\ distribuídas entre seus \\ membros e que lhe \\ concedem sua \\ preeminência \\ enquanto foco de \\ identidade social". \\ ${ }^{9}$ Para uma discussão \\ sobre Aids entre \\ mulheres ver, entre \\ outros, Barbosa \& \\ Villela, 1996; Knauth, \\ 1997; Parker \& Galvão, \\ 1996.
}


tenha mencionado, quando questionadas sobre o tipo de parto que esperavam, a cesariana. As principais justificativas dadas para a cesariana são a redução do risco de transmissão do vírus ao feto, indicação da equipe de saúde em função do HIV e, ainda, maior possibilidade de obter uma ligadura tubária. Outros motivos tais como experiências negativas com parto normal, medo da dor ou algum outro "problema de saúde" (cesarianas anteriores, pouca dilatação etc.) também são referidos; entretanto aparecem, em geral como argumentos secundários. Os depoimentos abaixo ilustram estas expectativas:

Esse aqui eu vou fazer cesárea, porque também evita o risco da criança pegar o vírus, né? (...) Evita também dele... nascer e ficar contaminado. Isso foi só no hospital, no começo da gestação eu perguntei pro Dr.Paulo. Bem no comecinho eu já perguntei pra ele: "E agora como é que eu faço? Quando a mãe ganha normal sai sangue aquela coisa toda, né?" (...) Ai ele me disse que não tinha problema, que eu podia optar pela cesariana, né? (...) Então desde o momento que eu fiquei gravida, eu já sabia que ia ser cesariana. - É? E como é que.. tu aceitaste isso? Como é que foram os teus outros partos?

- Tudo normal, já cheguei no hospital ganhando. (...) Fácil, fácil, fácil!

- Como é que tu vê isso, agora tem que fazer uma cesárea, depois dessa experiência de parto normal?

- Ai, tomara que não doa, porque parto normal dói pra caramba, nega! (riso) (...). Eu nunca fiz cesárea, eu não tenho experiência de cesárea ainda, né? Mas eu acho que se for para o bem do nenê vale a pena. Fica com um cortezinho na barriga, tomar uma anestesia. Ah, eu acho que vale a pena! (...) O importante é que a criança nasça com saúde. Não te incomodando depois... porque eles... assim, eles incomodam... pra fazer é ótimo, maravilhoso!

Olha, eu não sei se é uma boa, porque eu nunca tive, mas eu queria ter uma cesárea.(..) É, porque é menos chance de contaminação e outra que eu também já tô querendo operar, já faz tempo, né, não quero mais ter filhos, né. Aí, aproveitava, já, e fazia as duas coisas junto.

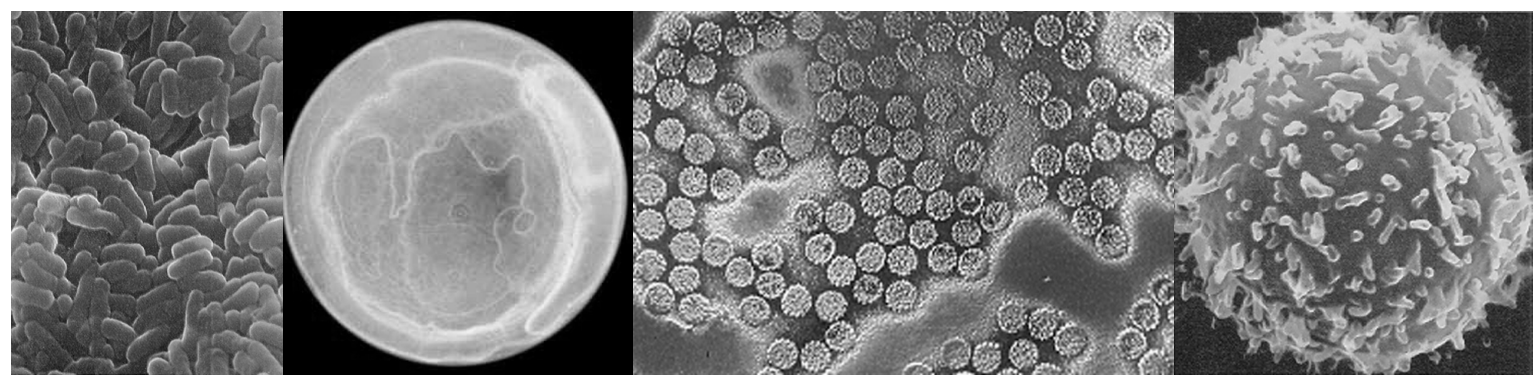




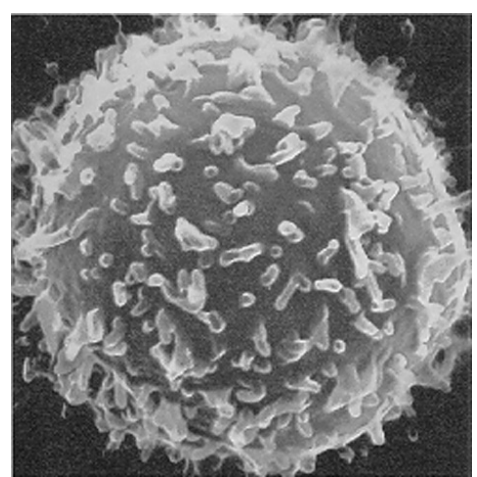

Linfócito "helper"

Assim, como se pode perceber, para grande parte das entrevistadas, especialmente para aquelas que manifestam a expectativa de um parto cesáreo, não são as experiências prévias positivas ou negativas o fator determinante na definição do tipo de parto "desejado", mas a saúde do bebê e a chance de realização da laqueadura. A diminuição do risco de transmissão vertical é acionada, muitas vezes, como justificativa para a cesariana e também para a esterilização, isto é, uma oportunidade a ser aproveitada para obter as duas coisas juntas.

A preferência pela cesárea encontra-se claramente vinculada ao discurso médico, ou melhor, a uma interpretação deste discurso. Isto faz com que, muitas vezes, a cesariana seja percebida como a única alternativa possível, como expressa uma entrevistada ao ser questionada a respeito das razões da escolha da cesariana: "Todos [partos] tem que ser cesárea, pra não contaminar o bebê, né”. Esta vinculação entre indicação médica e cesariana faz com que esta apareça relacionada a um sentimento de medo ou então contrariando um desejo inicial.

A Claudete. disse que lá no [determinado hospital], eles fazem mais cesárea. (...) Que foi comprovado num estudo que a cesárea...tem menos risco. Mas ela disse, que não, que não seja parto normal, que aí é parto induzido. (...) Agora eu já tava assim... quando me disseram que podia ser cesárea eu fiquei com medo, né? Porque eu nunca fiz cesárea, né? Ai, eu até fiquei com medo. Ai, Deus me livre se eu chego a pegar uma infeção hospitalar, eu sei que eu não posso pegar nada, né? Uma infecção, alguma coisa, né? Mas daí elas explicaram que é só ter cuidado, fazer a higiene direitinho, que não... que não tem problema nenhum...

A enfermeira Marta me disse que provavelmente eu vou fazer uma cesariana. Por causa das novas descobertas agora, né? (...) De redução da possibilidade, né! (...) E essa, provavelmente, vai ser cesariana, né, pelo o que ela me falou. (...) Eu preferia normal, né! (...) Eu, pra mi esse parto normal foi super bom, foi super rápido, foi bom. Minha recuperação foi ótima. No dia que eu voltei pra casa eu já queria lavar roupa no tanque.

O fato de a cesariana ser percebida enquanto prescrição médica faz com que o desejo seja colocado em segundo plano, pois mesmo as mulheres que expressam a vontade de ter um parto normal relativizam este desejo em função da indicação médica.

Não há, entretanto, uma orientação homogênea dos diversos serviços que atendem gestantes HIV+ em relação ao tipo de parto. Esta diferenciação de conduta é percebida também pelas gestantes que confrontam as diferentes informações recebidas, provindas de diferentes contextos, como evidencia a fala de uma entrevistada: 
- Eu conversei... com ela [médica] hoje, que eu pensei que fosse cesariana por conta da... do problema, né, do HIV. Mas não necessariamente, vai depender muito da posição que o neném estiver, essas coisas, mas eu estava mais querendo que fosse uma cesárea.

- E você preferia, na verdade, uma cesárea?

- Preferia, preferia. Até porque tem alguns comentários, que os médicos fazem... preferem fazer cesárea porque tira o neném mais rápido, né? Evitar muita contaminação, mas o pessoal me falou hoje que vai depender muito, né, da... (...) Acho que não foi nem ela [médica], foi com algum funcionário daqui, que eu conversei com tanta gente, né, que às vezes eles fazem cesárea até pra evitar a contaminação. Acho que varia também... de cada médico, né? Cesárea que é uma coisa mais rápida, do que ficar... que trabalho de parto você fica horas e horas ali, né? Então, mas pelo que ela [médica] me falou, não... não precisa necessariamente ser cesariana.

Ou ainda, como refere outra entrevistada ao confrontar informações distintas dadas por profissionais da mesma equipe:

Ah, não, eu... a doutora Paula falou que é melhor eu ter normal... a doutora Paula! Eu confundo, tanto médico... A doutora Débora falou que é melhor, que os meus parto são rápido. E porque eu posso sofrer, porque eu tenho o Daniel [filho caçula] que é pequenininho, e o... o... a... a cesárea ela é ruim. Porque o Daniel vai querer colo, muitas coisas que eu não... que eu faço num parto normal eu não vou poder fazer na cesárea. Aí eu falei pra ela: “Graças a Deus”, porque a cesárea, pelo que eu já vi, eu acho horrível. Mas eu falei pra ela: “Doutora Débora., lá a Assistente Social, quando eu fui pegar minha carta, ela falou assim: "Renata, dá um jeitinho de você pegar uma carta com a doutora, outra, sua médica lá onde você faz tratamento, pra você fazer o parto... é... a cesárea, porque a cesárea o neném corre menos risco". (...) Por... não, por causa do... do vírus. Ela disse, que é bem melhor pra cri... pro neném. Mas ela disse assim: "não compensa você fazer, porque o seu parto é rápido, você não... não sofre”. O que é realmente é verdade.

Há também, por parte das mulheres, uma interpretação do discurso médico, que é acrescida de informações de diferentes fontes, vindas do próprio contexto dos serviços de saúde (conversas na sala-de-espera, consultas com outros profissionais etc.) e de experiências pessoais, tanto suas como de pessoas próximas. É assim que, por exemplo, o parto normal é percebido como tendo menos risco que a cesariana, visto que esta é compreendida como uma cirurgia e, portanto, aparece vinculada ao risco de infecção e ao medo da anestesia.

A expectativa em relação ao parto passa ainda pelas possibilidades concretamente disponíveis. As mulheres acabam por conformar-se com sua 
inserção no sistema de saúde e sabem que a decisão sobre o parto está, em última instância, fora de seu poder e, em grande parte dos casos, fora mesmo do poder da equipe que a acompanhou no pré-natal. Este senso de realidade pode ser percebido claramente na resposta dada por uma das entrevistadas ao ser perguntada se já havia conversado sobre o tipo de parto pretendido com o médico do pré-natal:
Assim, se por um lado, é a condição de soropositividade para o HIV que faz com que o parto seja percebido como uma prescrição médica, deixando o desejo em segundo plano, por outro, é o tipo de serviço ao qual a gestante encontra-se vinculada que determinará o desfecho final, isto é, a maior ou menor probabilidade de realização da própria indicação.

\section{A determinação da cultura institucional}

É precisamente em relação aos encaminhamentos referentes ao parto $e$ contracepção que o papel assumido pelo tipo de serviço de pré-natal nas expectativas das gestantes fica mais evidente. Como já referido, quando o assunto é parto, a vontade das mulheres encontra-se condicionada à recomendação médica. Há, deste modo, uma correspondência entre a expectativa da gestante e o fato de o serviço ser mais ou menos incisivo quanto aos benefícios da cesariana. Esta influência do serviço pode ser percebida pelo tipo de argumento utilizado pelas mulheres para justificar suas preferências. É assim que, por exemplo, as gestantes dos serviços vinculados à universidade possuem, em geral, um discurso "mais técnico" enfatizando a diminuição do risco de transmissão vertical como justificativa para a cesariana. Em alguns casos, elas procuram incorporar as diferentes informações a que tiveram acesso, embora muitas vezes sem saber a lógica que as une a esta justificativa ${ }^{10}$.

É, diz que é, né. Não sei. Porque tem mais contato com o sangue da mãe, né. Mas não saiu ainda um parto seco, né, cesariana.... Eles... Eu não sei direito, né.... Faz a secagem da bolsa primeiro, não sei como, sei lá, depois é que faz o corte para tirar a criança. Eu não sei.

A médica falou que o mais seguro é... parto cesariana. (...) Eu acho que cesariana, porque... tem mais como... evitar... o.... contato do... acho que do sangue com a placenta do nenê.

\footnotetext{
${ }^{10}$ Sobre a incorporação de categorias médicas ao discurso leigo ver Boltanski, 1984.
} 


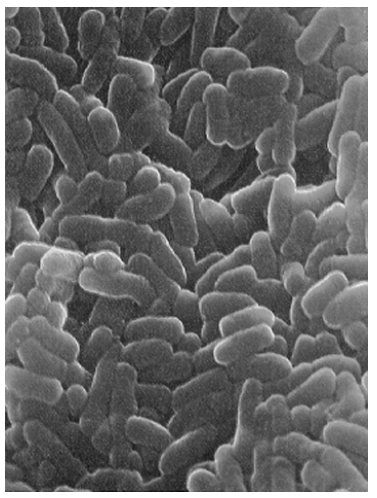

Bacilos de Koch
Evita também dele... nascer e ficar contaminado. Isso ai ao foi só no hospital, no começo da gestação eu perguntei pro Dr. Bem no comecinho eu já perguntei pra ele: "E agora como é que eu faço?" Quando a mãe ganha normal [parto] sai sangue, aquela coisa toda, né! Por isso que é maior [risco] realmente. Aí ele me disse que não tinha problema, que eu podia optar pela cesariana, né?

Por outro lado, a preferência pelo parto normal, que, na cidade de Porto Alegre aparece mais freqüentemente nas pacientes do serviço considerado como típico do SUS e, em São Paulo, encontra-se distribuída de forma mais ou menos equivalente entre os três tipos de serviço, aciona como argumento as experiências prévias positivas, a recuperação mais rápida e o medo da cesariana. O risco, nesta perspectiva, está vinculado à cirurgia - infecção, inflamação dos pontos, anestesia - e não à transmissão do vírus ao feto.

Assim, as expectativas em relação ao tipo de parto não são determinadas apenas pela condição de soropositividade para o HIV, mas também pelo discurso e prática institucional e pela avaliação que as próprias gestantes fazem do contexto no qual encontram-se inseridas, isto é, pela maior ou menor possibilidade de alcançar suas expectativas.

Entretanto, para além dos serviços percebe-se, claramente, que há a determinação do que poderíamos chamar de uma cultura médica local. Outros estudos (Potter, 1999; Hopkins, 2000) já demonstraram o quanto a formação médica e a cultura local são importantes para a posição assumida pelo profissional e pelos serviços de saúde em relação à esterilização cirúrgica. Este fator é também evidenciado pela distribuição desigual entre as diferentes regiões do país da prática de ligadura tubária, em que o Rio Grande do Sul aparece sempre com os menores índices. No caso das gestantes HIV+ aqui analisado, é esta cultura médica que explica as diferentes expectativas das entrevistadas de São Paulo e de Porto Alegre no que se refere à ligadura tubária. Pois se em ambas as cidades há um grande desejo por parte das mulheres pela cirurgia, a avaliação de sua viabilidade é bastante distinta nos dois contextos. Na cidade de São Paulo há a percepção de que os serviços tendem a facilitar e, por vezes, estimular, a realização da laqueadura, o que deixa as gestantes mais confiantes quanto à concretização desta expectativa, como expressam os depoimentos abaixo:

É, vou com bastante dor, que é pra não chegar e ficar ainda no soro, ficar fazendo exame de toque. Assim, já chega, já ganha $e$ pronto. Aí eu já espero dar aquela dor. Agora, esse aqui, não. Esse aqui vai ser diferente, porque a médica explicou pra mim, que eles tão querem fazer cesárea, pra poder fazer a laqueadura, né. Mas, se não der vai fazer normal e depois a laqueadura, né. (...) Então, me deixou alerta. Eu preferia fazer cesárea, porque já fazia uma coisa só. (...) Porque já fazia tudo de uma vez só, já fazia a laqueadura e tudo. Agora, o normal, não. Você vai ter que fazer o normal $e$ depois voltar de novo pra fazer a laqueadura. 
- Ah, eu, por mim, queria ter normal. (riso) Porque todo mundo fala que o normal, a dor é na hora, depois passa. Da minha menina, não, a dor foi na hora, depois. Fui embora pra casa com dor, a operação não secava de jeito nenhum, demorou muito.

- Mas, vai poder ser parto normal?

- Não, vai ter que ser cesárea porque eu vou me laquear, né. Ainda assim eu perguntei se caso nascesse normal, se podia fazer a laqueadura. Aí, disse que podia operar depois de três meses, fazer a laqueadura, né. Sei lá, eles falam que é cesárea, se pudesse escolher, eu queria normal.

Não, ela [médica] falou pra mim: "Olha você vai ser cesárea, eu vou te orientar mais, a gente vai conversar mais da próxima vez." Mas ela [médica] me falou, ainda mais que eu falei pra ela que eu quero operar, né. Falei: "Não, eu quero operar, onde e com quem eu falo? Eu já quero resolver, já quero já ficar tranqüila.” (...) Porque aí já faz a cesárea depois já opera, tudo. Já que vai ter, faz tudo de uma vez só, né. Não quero mais ter filho, não.

Mas se em São Paulo não aparecem maiores restrições dos serviços em relação à laqueadura, em Porto Alegre as entrevistadas evocam diversos elementos que dificultam a obtenção desta cirurgia, tais como a pouca idade da gestante, o fato de que são poucos os hospitais e/ou profissionais que realizam este procedimento, a necessidade de que seja durante uma cesariana. Na percepção das mulheres, os serviços de saúde da cidade de Porto Alegre são pouco favoráveis à ligadura tubária e os profissionais, por sua vez, procuram postergar a decisão, passando para outro profissional, em geral o médico do plantão a responsabilidade por tal procedimento. É assim que apesar de manifestarem claramente o desejo de fazer uma cesariana na esperança de obter uma laqueadura, as entrevistadas de Porto Alegre possuem o entendimento de que esta será uma empreitada difícil

- É mais perto e o Dr. Paulo diz que é melhor, porque ali já tem mais recurso né? Porque eu queira fazer desligamento. Mas ele disse pra mim que depende lá do... Do médico é! E depende dele, porque ele tem que tá lá pra assinar. Eu quero, porque eu pretendo fazer desligamento.

- E se tu não conseguir fazer agora, o que tu vai fazer, tu pretende ter outro filho?

- Não! Não, mas tendo ele ali eu faço desligamento, nem que seja na marra. Eu quero fazer, eu não quero mais...

É, mas todo mundo diz que fazer ligamento tem que ter... ai, como é que se diz, tem que ter aquele problema de só fazer cesárea, daí eles fazem ligamento. Se eu ganho normal eu acho que não fazem. (...) E desse eu não... se for parto normal aí não dá daí [para fazer laqueadura]. Eu podia até pedir, né? Já que eu tenho esse problema [HIV], eu já podia, no embalo e já pedir, né? 
As mulheres possuem uma clara noção de que além de sua vontade, outros fatores influenciam a obtenção ou não da laqueadura. É consenso entre elas que um grande facilitador é a cesariana. Entretanto, enquanto que as entrevistadas de São Paulo indicam a possibilidade, oferecida em geral pelo próprio serviço, de realizar o procedimento em outro momento, para as gestantes de Porto Alegre esta possibilidade não está colocada. Na percepção dessas mulheres, se já vai ser difícil conseguir uma laqueadura durante o parto, pois mesmo no caso de uma cesariana será necessário acionar o argumento da soropositividade para o HIV, mais remota ainda serão as chances de obtê-la em outro momento. Até porque além do acesso ao serviço e da burocracia necessária, terão dificuldades em liberar-se dos encargos domésticos e de trabalho. Esta percepção faz com que muitas mulheres, apesar de desejarem uma laqueadura, não abordem esta questão durante o pré-natal.

\section{A frustração do desejo}

Considerando as expectativas anteriores e o tipo de parto realizado, temos que aproximadamente metade das entrevistadas conseguiu realizar o tipo de parto esperado. Entretanto, é interessante notar que muitas entrevistadas, mesmo aquelas que conseguiram realizar o tipo de parto que esperavam, avaliam negativamente a experiência. Os relatos abaixo ilustram esta avaliação:

Eu queria que ela [filha] nascesse de 9 [meses], mas não deu pra esperar mais. Por que eu fiz um exame carga viral e o exame deu um pouco alto, né. E eu como tava tomando só um medicamento e era pra tomar dois, tava tomando um então teve um pouco mais de risco. Então ela foi tirada com 8 meses e foi uma cesárea, né. Eu gostaria que fosse parto normal como eu ganhei o meu guri, gostaria muito que fosse parto normal. Mas, tudo bem, ela veio bem, nasceu bem. Eu queria um parto normal. (...) É, o médico dizia que provavelmente era parto normal. Só que tudo dependia do resultado desse exame que eu fiz da carga viral. Aí como veio essa carga viral alta foi decidido que ia ser cesárea. (...) Eu preferia mil vezes o parto normal. Porque o parto normal eu vim pra casa $e$ comecei a caminhar, foi bem melhor! A cesárea não. A cesárea eu ficava doída por dentro. Já me doía bastante tempo. Tinha bastante dor dentro da barriga porque foi aberto, né! Foi mais difícil pra caminhar tudo, né. E quando eu tirei os pontos ainda abriu um pouquinho, não tava bem, né.

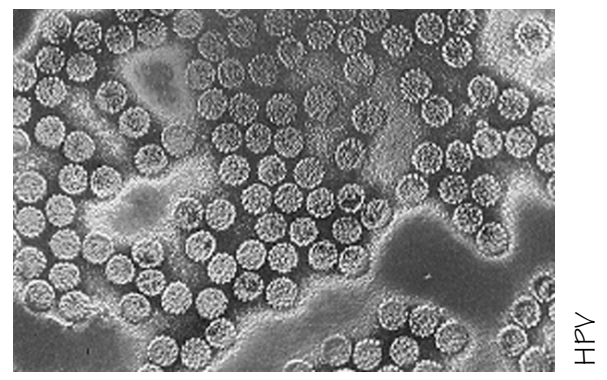




\begin{abstract}
Os outros partos foi normal, foi parto normal. (....) Foi mais demorada [a recuperação do último parto], porque de primeira, com os pontos, quando eu cheguei do hospital com os pontos eu já comecei batendo nela [filha mais velha] que ela me fez passar nervoso (...), já comecei passar nervoso. Eu já vi que o clima pra mim já ia ser de, como é que fala?... resguardo quebrado, né. Que o meu resguardo seria quebrado, de passar nervoso, e daí o médico disse que não podia passar nervoso, né, que eu não podia passar nervoso, mas que eu teria que ir em frente, passando nervoso ou não.
\end{abstract}

Parece que, para grande parte das mulheres, as expectativas iniciais em relação ao tipo de parto, definidas em grande parte em função da condição de soropositividade para o HIV, não correspondem à experiência do parto, tanto em razão desta mesma condição como em virtude de experiências anteriores e/ou outras expectativas. Dito de outra forma, as mulheres, embora "convencidas" de que a cesariana é a melhor opção, seja por reduzir os riscos de transmissão do vírus ao feto, seja por propiciar uma laqueadura tubária, acabam por interpretar a experiência do parto e pós-parto a partir de outras concepções e valores.

Assim, se o desejo por determinado tipo de parto ou as experiências anteriores cedem facilmente diante dos argumentos médicos, sobretudo quanto avaliadas de uma perspectiva racional (por exemplo, ao utilizarem uma relação tipo custo/benefício) e durante a gestação, portanto com um certo distanciamento, o mesmo não ocorre quando o que está em questão é a avaliação da experiência. Os parâmetros do discurso médico, que até então serviam para balizar as expectativas em relação ao parto, parecem não dar conta desta prática. Ao falarem sobre seu parto e puerpério, as entrevistadas enfatizam as sensações corporais - recuperação mais difícil, dor - mas também os aspectos morais vivenciados ${ }^{11}$ - como por exemplo o nervoso, a quebra de resguardo ou ainda as situações de mau atendimento e discriminação dentro dos serviços de saúde. E nesta avaliação, as percepções anteriores e desejos são acionados como um dos elementos para explicar a negatividade da experiência. $O$ fato de as expectativas relacionadas ao parto serem determinadas por uma prescrição médica, que pouco depende da vontade ou experiências anteriores, faz com que para muitas mulheres esta experiência seja percebida como mais difícil que os partos anteriores ou pior que o esperado.

\section{Buscando na cultura o sentido para a prevenção}

Ao deslocarmos o eixo de análise dos comportamentos individuais para o contexto social mais amplo ${ }^{12}$ diversas questões emergem. No caso específico que estamos analisando, passamos a perceber que as decisões reprodutivas não se dão apenas na esfera privada, mas são condicionadas por um conjunto de fatores institucionais e culturais que ultrapassam os desejos $e$ experiências individuais. Por outro lado, é muito difícil distinguir as

\footnotetext{
${ }^{11}$ Para uma discussão mais aprofundada a respeito da concepção físico-moral acionadas pelos membros dos grupos populares no Brasil ver Duarte, 1996.
}

12 Para uma crítica aos modelos de prevenção centrados no indivíduo ver, entre outros, Parker, 1994. 


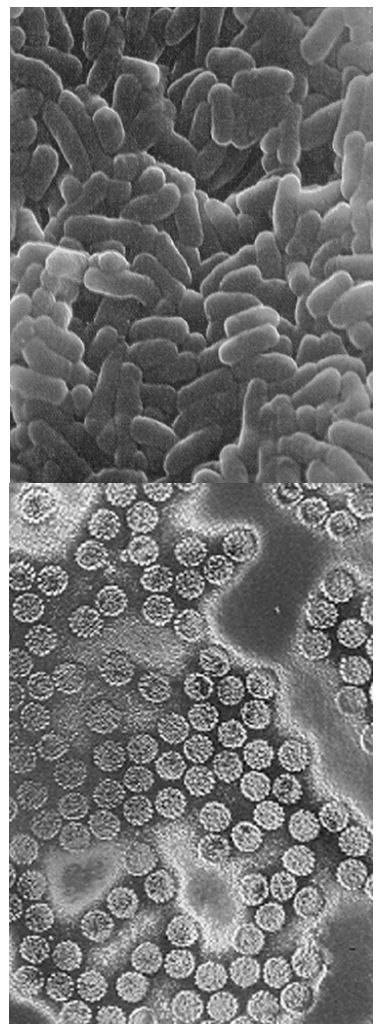

fronteiras entre os condicionantes de ordem institucional e aqueles de ordem cultural, visto que há, entre eles, um movimento de dupla determinação, pois ao mesmo tempo que a instituição determina limites de ordem concreta, a cultura os justifica e lhes dá significado.

Os desejos e práticas individuais situam-se neste emaranhado e se constróem nesta relação, isto é, eles não existem descolados do contexto no qual são produzidos e ao qual se referem. É interessante notar, todavia, que o contexto de significação acionado pelos indivíduos pode ser, em determinada situação, um contexto macro-social ou institucional e, em outra, um contexto mais local, permeado por valores e concepções específicas. No caso das gestantes infectadas pelo HIV, por exemplo, percebese claramente a influência do contexto institucional na construção das expectativas em relação ao tipo de parto e à ligadura tubária. Por outro lado, quando o que está em questão é a avaliação do parto, são as experiências anteriores e sensações físico-morais que darão significado à experiência.

Retomando Bajos e Marquet (2000), a multiplicidade de determinações ou de diferentes níveis, que interferem no comportamento individual, exige que também tenhamos uma perspectiva multidimensional. A ação em apenas um dos níveis, embora possa até produzir resultados concretos como, no caso em análise, a redução das taxas de transmissão vertical do HIV, não basta para dar significado ao conjunto das percepções e práticas dos indivíduos. Assim, como vimos, o fato de as mulheres deixarem em segundo plano suas experiências e desejos em função de uma recomendação médica, não impede que avaliem sua experiência a partir de outros valores e mesmo que, em outro momento, coloquem em cheque o próprio discurso médico como, por exemplo, quando não seguem a recomendação de uso do preservativo com o parceiro ou ainda quando pouca importância dão ao acompanhamento médico e uso de medicação no pós-parto.

Podemos nos questionar ainda o quanto esta não correspondência entre expectativa e experiência pode influenciar os comportamentos futuros. Será que estas gestantes que "abriram mão" da vontade de ter um parto normal e avaliaram negativamente a experiência da cesariana terão a mesma disponibilidade em aceitar as recomendação médicas? E como se comportarão aquelas mulheres que, em função do contexto institucional $e$ da cultura médica local, não conseguiram realizar a desejada laqueadura tubária, mesmo tendo se submetido a uma cesariana, condição tida como facilitadora? Será que estas recorrerão a uma nova gestação como mais uma tentativa de conseguir a cirurgia ou então se conformarão com outro método contraceptivo, mesmo que este seja percebido como mais problemático e ineficaz?

Estas questões fazem-nos pensar que as práticas de saúde, sobretudo aquelas de caráter preventivo, só são de fato eficazes quando fazem sentido para as pessoas implicadas. E para isto elas devem articular os diferentes níveis ou esferas da vida social. Mas que ponto tomar para esta articulação: o indivíduo, a cultura ou a ordem macro-social? À primeira vista, o indivíduo parece ser o ponto mais palpável; entretanto, é necessário reconhecermos que os indivíduos se constróem numa cultura e portanto, não existem como 
tal isoladamente. Dessa forma, a cultura ou o contexto local aparece como o plano privilegiado de articulação com os demais. É nele que os indivíduos são socializados, aprendem valores e práticas, recebem determinados conhecimentos, enfim, constróem suas representações e sua visão de mundo. Por outro lado, ao privilegiarmos como objeto de intervenção o contexto local estaremos lidando, inexoravelmente, com as determinações macro-estruturais, ou melhor, com a forma como estas determinações incidem tanto na cultura como no cotidiano dos indivíduos.

O contexto local é também o plano que determina as possibilidades $e$ padrões de relacionamentos, sejam estes afetivos, sexuais ou familiares. É no próprio cotidiano dos indivíduos que as experiências se realizam e os valores se atualizam.

Entretanto, permanecem alguns desafios ao privilegiar-se o que chamamos aqui de contexto local ou cultural. O primeiro deles, é como inserir os indivíduos e grupos num contexto mais amplo que leve em consideração o conceito de vulnerabilidade tanto individual como o social. Ou seja, como agir localmente sem perder o caráter político mais amplo das práticas preventivas? O outro desafio diz respeito ao impasse que se coloca entre o respeito a valores e práticas culturais e a própria prevenção, que é por si só normativa. É necessário, sem dúvida, conhecer e respeitar os valores dos diferentes grupos sociais. Respeitar não significa, entretanto, reificar. O respeito pelo outro é sempre um bom começo para o diálogo.

\section{Referências}

BAJOS, N., MARQUET, J. Research on HIV sexual risk: social relations-based approach in a cross-cultural perspective. Soc. Sci. Med.,v. 50, p.1533-46, 2000.

BARBOSA, M. R., VILLELA, W. V. A trajetória feminina da Aids. In: PARKER, R., GALVÃO, J. (Orgs.) Quebrando o silêncio: mulheres e Aids no Brasil. Rio de Janeiro: Relume Dumará/Abia/IMS/UERJ, 1996. p. 17-32.

BILAC, E. Famílias de trabalhadores: estratégias de sobrevivência. São Paulo: Símbolo, 1978.

BOLTANSKI, L. As classes sociais e o corpo. Rio de Janeiro: Graal, 1984.

DUARTE, L. F. D. Da vida nervosa nas classes trabalhadoras. Rio de Janeiro: Zahar, 1986.

FONSECA, C. Valeur Marchande, Amour Maternel et Survie: Aspectos de la Circulation des Enfants dans en Bindonville Brésilien. Ann. ESC, n.5. p.991-1022, 1985.

FONSECA, C. Alliés et ennemis en famille. Temps Mod., n.499, p.28-58, 1988.

HOPKINS, K. Are brazilian women really choosing to deliver by cesarean? Soc. Sci. Med., v.5, n. 51, p.725-40, 2000.

KNAUTH, D. R. O vírus procurado e o vírus adquirido. Estudos Feministas, v.5, n.2, p.291-302, 1997.

PARKER, R. A construção da solidariedade. Rio de Janeiro: Relume Dumará/Abia/IMS/UERJ, 1994.

PARKER, R., GALVÃO, J. (Orgs.) Quebrando o silêncio: mulheres e Aids no Brasil. Rio de Janeiro: Relume Dumará/ Abia/IMS/UERJ, 1996.

POTTER, J. E. The persistence of outmoded contraceptive regimes: the cases of Mexico and Brazil. Popul. Dev. Rev., v.4, n. 25, p.703-39, 1999.

POTTER, J. E. et al. Inquities and policy dilemmas in the course of an unregulated, spontaneous fertility transition: the case of Brazil. In: CONFERÊNCIA GERAL DE POPULAÇÃO IUSSP, 24, 2001, Salvador. Anais... Salvador, 2001.

POTTER, J. E., BERQUÓ, E., PERPETUO, I.H., LEAL, O.F., HOPKINS, K., SOUZA, M.R., FORMIGA, M.C. Unwantd caesarean sections among public and private patients in Brazil: prospective study. Br. Med. J., v.323, n.7322, p.1155-8, 2001. 
SALEM, T. Mulheres faveladas: com vendas nos olhos. Perspect. Antropol. Mulher, n.1, p.49-99, 1981.

SARTI, C. A. A família como espelho: um estudo sobre a moral dos pobres. Campinas: Autores Associados, 1996.

THE EUROPEAN MODE OF DELIVERY COLLABORATION. Elective caesarean-section versus vaginal delivety in preventio of vertical HIV-1 transmission: a randomised clinical trial. The Lancet, v.353, mar. 27, p.1035-9, 1999.

THE INTERNATION PERINAL HIV GROUP. The mode of delivery and the risk of vertical transmission of human immunodeficiency virus type 1. N. Engl. J. Med., v. 340, n.13, p. 977-87, 1999.

VAN CAMPENHOUDT, L, COHEN, M., GUIZZARDI, G., HAUSSER, D. (Eds.) Sexual interaction and HIV risk: new conceptual perspectives in European Research. London: Taylor \& Francis, 1997.

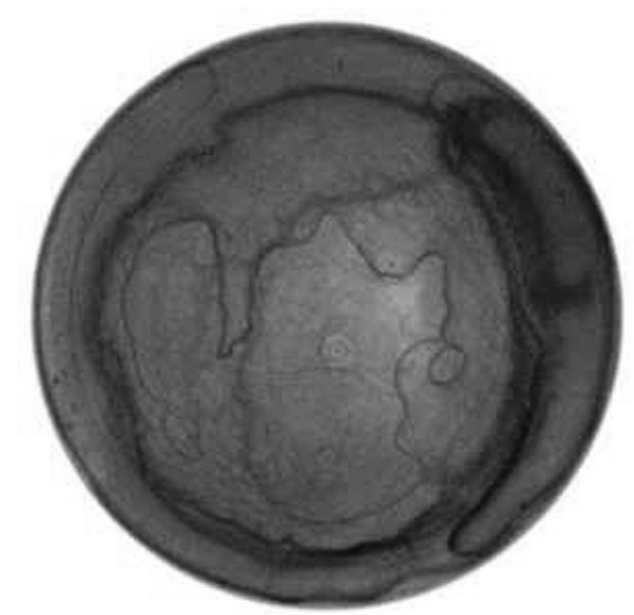

FÁBIO DE CARVALHO,

O futuro se repete no passado - n.1, 1999/2000

(cópia fotográfica de imagem digital a partir de manchas de café no fundo de canecas)

KNAUTH, D. R. ET AL. Cultura médica y decisiones reproductivas entre mujeres infectadas por el virus del SIDA, Interface _ Comunic, Saúde, Educ, v.6, n.11, p.39-54, 2002.

Las gestantes contaminadas con el virus del SIDA se deparan con un conjunto de informaciones, prescripciones y prácticas que tornan este período de forma particular en relación a otras gestaciones y experiencias. El actual articulo busca evidenciar los factores que condicionan las posibilidades reproductivas de las gestantes HIV+, en especial con referencia al tipo de parto y decisiones en relación a la esterilización femenina así como sus implicaciones. Los datos presentados son el resultado de una pesquisa desarrollada en las ciudades São Paulo y Porto Alegre, donde fueran entrevistadas 60 mujeres. La condición de suero positiva para el SIDA hace que el parto sea sentido, por las gestantes, como una prescripción médica dejando las ansias en segundo plano. Además de este factor, el tipo de servicio al cual la gestante se vincula, surge como determinante tanto para la indicación ofrecida como para la concretización o no. El hecho de que las expectativas relacionadas al parto estén determinadas por una prescripción médica, que poco dependen de las ansias o experiencias anteriores, hace que para muchas mujeres esta experiencia sea percibida como más difícil que los partos anteriores o peor que lo esperado.

PALABRAS CLAVE: Conducta anticonceptiva; medicina reproductiva; Síndrome de inmunodeficiencia adquirida; parto. 
KNAUTH, D. R. ET AL.

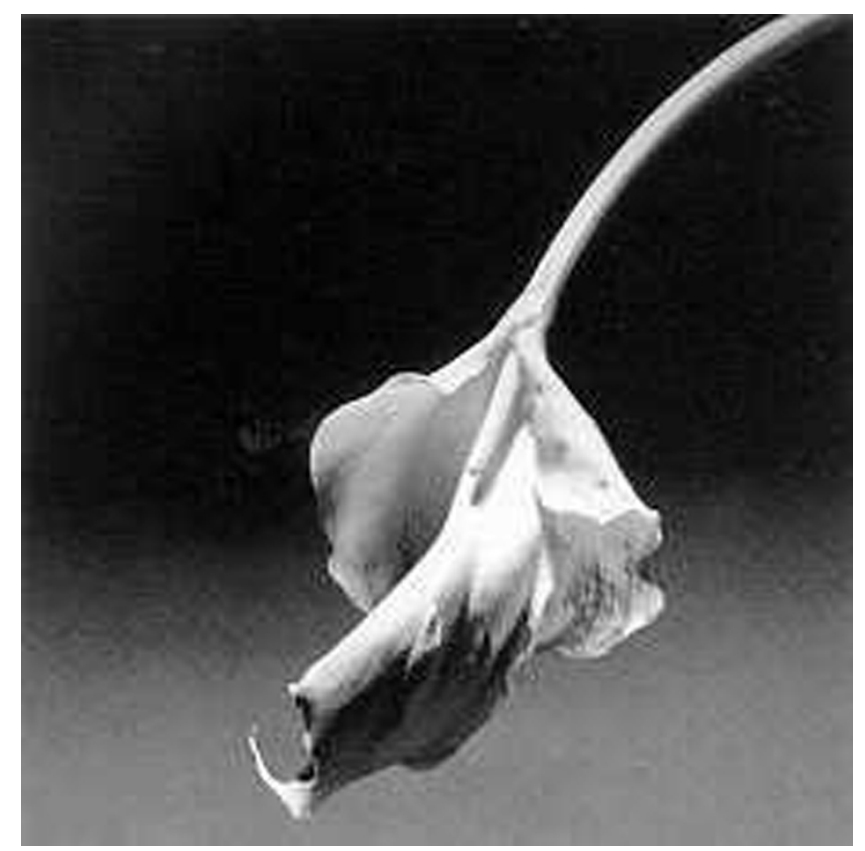

MAPPLETHORPE, Lírio

54 Interface - Comunic, Saúde, Educ, v6, n11, p.39-54, ago 2002 